\title{
Bank Credit and Aggregate Import Demand in South Africa: An Autoregressive Distributed Lag Approach
}

\author{
Emmanuel Ziramba \\ Professor of Economics, Department of Economics, \\ University of Namibia, Windhoek, Namibia \\ Johanna Mumangeni \\ Department of Economics, University of Namibia, Windhoek, Namibia \\ doi: 10.19044/esj.2017.v13n16p71 URL:http://dx.doi.org/10.19044/esj.2017.v13n16p71

\begin{abstract}
This study reformulated the aggregate import demand function for South Africa by incorporating a financial variable, bank credit. The study used the bounds testing approach for cointegration and the autoregressive distributed lag models to estimate short-run and long-run elasticities of aggregate import demand. The cointegration results confirm a long run relationship between the quantity of imports and the explanatory variables. Although bank credit has a positive impact on aggregate imports, it is statistically insignificant. It is statistically significant in the short-run. Our results suggest that bank credit is insufficient as a policy instrument for longterm import demand in South Africa. It can only be useful in managing the South African external balance in the short-run.
\end{abstract}

Keywords: Bank credit, cointegration, aggregate import demand, South Africa

\section{Introduction}

South Africa's aggregate imports rose significantly over the years. Imports have outstripped exports over time. This resulted in an increasing current account deficit. According to the World Bank database, the current account deficit rose 0.67 percent of GDP in 1960 to 4.3 percent of GDP in 2015. In 2013 it reached 5.8 percent of GDP (Straus, 2015). The current account deficit reflects an excess of expenditure over income.

Due to the importance of aggregate import demand there are several studies which have tried to explain the behaviour of the import demand function in South Africa. Among such studies are Gumede (2000), Truett and Truett (2003), Ziramba (2008), and Ziramba (2012). These studies have used both the single economic activity variable as well as components of 
expenditure to explain the behaviour of aggregate imports in both the short and long-run periods. Such studies have given important insights on the determinants of aggregate imports in South Africa. However, none of the earlier studies has included financial variables in their specification of the aggregate import demand function. Following Craigwell (1994), this study includes bank credit as a possible determinant of South Africa's aggregate import demand.

The rest of the paper is arranged as follows. Section 2 gives an overview of the empirical literature on the relationship between financial variables and import demand. Section 3 outlines the methodology that was employed in the study. Section 4 gives the empirical results and section 5 concludes the study.

\section{Literature Review}

From the literature survey only four studies have touched on the inclusion of bank credit in the import demand function. The first study is by Craigwell (1994). Craigwell estimated modified forms of the aggregate import demand function for Barbados over the annual period 1960 to 1993. His study made three modifications to the traditional import demand function. Firstly, it disaggregated the domestic price index into the trade and non-traded price indices. Secondly, it included credit from the banking system as an additional variable in the model. Lastly, a dummy variable was included for a multi-national firm, Intel, which had left the country in 1987.

Craigwell (1994) modelled import demand in log-linear form. The time series properties of the data were examined using the augmented Dickey -Fuller and the Phillips-Perron unit root tests. All the variables were found to be integrated of order one. The Johansen cointegration test was used to test for a long-run relationship. The study finds evidence of cointegration between import demand and its determinants. Income and bank credit variables were found to be significant. It justifies the inclusion of nontraditional variables like bank credit in modelling import demand in Barbados.

The second study is by Tang (2004). Tang (2004) re-examined the Japanese aggregate import demand function using a modified model. The model included financial variables such as bank credit, lending rate, deposit rate, government bond yield and share prices. It also included an accounting identity where the trade balance is the difference between savings and investments. In this specification factors which influence savings and investment may also influence the trade balance or trade flows (exports and imports). The study's empirical results indicate evidence of cointegration among the variables included. This finding supports the inclusion of financial variable(s) in the Japanese aggregate import demand models. 
The third study is by Tang (2006). Tang (2006) re-estimated the aggregate import demand function for five Southeast Asian countries using a modified model. The countries were Malaysia, Singapore, Indonesia, Thailand and the Philippines. The model included bank credit as an additional variable together with the traditional import determinants, namely relative price of imports and the economic activity variables. For the economic activity variable, their study used the activity variable proposed by Senhadji (1998) that is calculated by subtracting real exports from real GDP. Different sample periods were used for the different countries (Malaysia, 1960-2000; Singapore, 1974-2000; Thailand, 1960-2000; Indonesia, 19602000; the Philippines, 1960-2000). The bounds test approach to cointegration was used to examine the long run relationships in the five countries. The long run elastisticities were estimated using the autoregressive distributed lag model. The null hypothesis of no cointegration among the variables was rejected in the cases of Indonesia and Thailand. This result suggests long run relationships between the volume of imports, domestic economic activity, relative price of imports and bank credit in these countries. This finding supports the inclusion of bank credit in estimating the aggregate import demand function for those economies. All three determinants of aggregate imports were found to be statistically different from zero in both Indonesia and Thailand. The bank credit variable was found to be positive in both countries.

The fourth study is by Omoke (2012). Omoke (2012) examined a reformulated aggregate import demand function for Nigeria over the period 1970 to 2009. The author incorporated bank credit variable into the traditional import demand function. The other variables included are the economic activity variable as well as the relative prices. The model is specified as log-linear. The time series properties of the series are examined using the augmented Dickey Fuller and Phillip-Peron unit root tests. The Johansen multivariate methodology was used to estimate the model. The results of the study show no evidence of cointegration between import demand and bank credit.

\section{Methodology}

$M_{t}=f\left(Y_{t}, R P_{t}, B C_{t}\right)$

Where $M_{t}$ is the quantity of imports demanded at time t. $Y_{t}$ is the scale variable representing the level of domestic activity. This study uses the real gross domestic product as a scale variable. $\mathrm{RP}_{\mathrm{t}}$ is the relative price of import which is defined as the ratio of import price index to the domestic price level.

In log linear form equation (1) can be expressed as $\ln M_{t}=\beta_{0}+\beta_{1} \ln Y_{t}+\beta_{2} \ln R P_{t}+\beta_{3} \ln B C_{t}+\varepsilon_{t}$ 
Where $\beta_{0}$ is a constant and $\varepsilon_{\mathrm{t}}$ is the random error term which is not serially correlated while all the variables are as defined before. The macroeconomic components of final demand are expected to affect aggregate imports positively $\left(\beta_{1}>0\right.$, and $\left.\beta_{3}>0\right)$. An increase in the relative price of imports is expected to reduce imports $\left(\beta_{2}<0\right)$.

The bounds testing approach to cointegration does not require knowledge of the order of integration or cointegration ranks of the variables. The test consists of estimating the following unrestricted error correction model:

$\Delta \ln M_{t}=\lambda_{0}+\lambda_{1} \ln M_{t-1}+\lambda_{2} \ln Y_{t-1}+\lambda_{3} \ln B C_{t-1}+\lambda_{4} \ln R P_{t-1}+\sum_{i=1}^{m} \alpha_{5 i} \Delta \ln M_{t-i}$ $+\sum_{i=0}^{m} \alpha_{6 i} \Delta \ln Y_{t-i}+\sum_{i=0}^{m} \alpha_{7 i} \Delta \ln B C_{t-i}+\sum_{i=0}^{m} \alpha_{8 i} \Delta \ln R P_{t-i}+\varepsilon_{1 i}$

Here $\Delta$ denotes the first difference operator, the other variables are as defined above. The F test proposed by Pesaran et al., (2001) can be used to determine whether a long-run relationship exists through testing the significance of the lagged levels of the variables. If such a relationship exists among the variables, the $\mathrm{F}$ test indicates which variable should be normalized.

The bounds test methodology suggests analysing the null hypothesis of no co-integration through a joint significance test of the lagged levels of the variables. The null hypothesis of no cointegration among the variables in equation (3) is $\left(\mathrm{H}_{0}: \lambda_{1}=\lambda_{2}=\lambda_{3}=\lambda_{4}=0\right)$ against the alternative hypothesis $\left(\mathrm{H}_{1}: \lambda_{1} \neq 0\right.$,or $\lambda_{2} \neq 0$, or $\lambda_{3} \neq 0$, or $\left.\lambda_{4} \neq 0\right)$.

We test the null hypothesis of no co-integration by means of the $F$ test. Pesaran et al., (2001) have established that, under the null hypothesis of no co-integration and regardless of the degree of integration of the variables, the asymptotic distribution of the obtained F-statistic is non-standard. It follows an asymptotic $\chi^{2}(\mathrm{~m})$ under the null, where $\mathrm{m}$ is the number of restrictions. They develop two bounds of critical values for the different model specifications: upper bound applies when all variables are integrated of order one, I(1) and the lower bound applies when all the variables are stationary, I(0). However, these critical values are generated on sample sizes of 500 and 1000 observations and 20000 and 40000 replications, respectively. Narayan and Narayan (2005) argue that such critical values cannot be used for small sample sizes like the one in this study. Given the relatively small sample size in the present study (40 observations) we extract the appropriate critical values from Narayan (2005) which were generated for small sample sizes of between 30 and 80 observations. 
If the computed $F$-statistic, for a chosen level of significance, lies outside the critical bounds, a conclusive decision can be made regarding co integration without knowing the order of integration of the regressors. If the estimated test statistic is higher than the upper bound, the null hypothesis of no co-integration is rejected. If the $F$-statistic is lower than the lower bound then the null hypothesis cannot be rejected. If the $F$-statistic lies between the lower and the upper bounds, conclusive inference cannot be made. By adopting Pesaran et al. (2001)'s approach for co-integration analysis, a pretest for unit root (degree of integration) of the interested series is not necessary.

The chosen methodology, which is based on the estimation of an unrestricted error-correction model (UECM), has certain preference over other co integration tests. First, Pattichis, (1999: 1062) has argued that the UECM is likely to have better statistical properties because it does not push the short-run dynamics into the residual term as in the Engle-Granger (1987) technique. Second, it can be applied to studies that have finite samples unlike the Engle-Granger (1987) approach, which suffers from considerable small sample bias (Mah, 2000: 240). Third, the bounds test procedure is applicable irrespective of whether the underlying explanatory variables are integrated of order zero (I (0)) or one (I (1)) (Mah, 2000: 240). In other words, it avoids the pre-testing problems associated with standard co-integration analysis which requires the classification of variables into I(0) and I(1) (Pesaran et al. 2001). Fourth, another important advantage of the bounds test procedure is that estimation is possible even when the explanatory variables are endogenous, and is sufficient to simultaneously correct for residual serial correlation. However, it has to be pointed out that this procedure (method) is inappropriate if there is more than one co integrating relationship involving the dependent variable. In our case this does not apply since we only have two variables in our system.

\section{Long run elasticities}

If there is a long run relationship between import demand, relative prices and the expenditure components, the long run elasticities can be estimated using the equation specified below:

$\ln M_{t}=\beta_{0}+\sum_{i=1}^{k} \beta_{1 i} \ln M_{t-i}+\sum_{i=0}^{k} \beta_{2 i} \ln B C_{t-i}+\sum_{i=0}^{k} \beta_{3 i} \ln Y_{t-i}+\sum_{i=0}^{k} \beta_{4 i} \ln R P_{t-i}+\varepsilon_{t}$

Equation (5) above represents the long run relationship however, for policy reasons, it is necessary to estimate the short run equation to capture the speed of adjustment (Constant \& Yue, 2010). This is shown below in equation (6) 


\section{Short run elasticities}

$$
\begin{aligned}
& \Delta \ln M_{t}=\delta_{0}+\sum_{i=1}^{k} \delta_{1 i} \Delta \ln M_{t-i}+\sum_{i=0}^{k} \delta_{3 i} \Delta \ln B C_{t-i}+\sum_{i=0}^{k} \delta_{4 i} \Delta \ln Y_{t-i}+ \\
& \sum_{i=0}^{k} \delta_{5 i} \Delta \ln R P_{t-i}+\psi E C M_{t-1}+\mu_{t}
\end{aligned}
$$

Where, $\psi$ measures the speed of adjustment to obtain long-run equilibrium in the event of shocks to shocks to system. $E C M_{\mathrm{t}-1}$ is the error correction term.

\section{Empirical analysis and results}

\section{Time series properties of the data}

This study covers the sample period 1965 to 2014. All the variables are measured in constant 2000 United States dollars. All the data were obtained from the World Bank's World Development Indicators (CD-ROM). The relative price of imports which is the ratio of $\mathrm{P}_{\mathrm{M}} / \mathrm{P}_{\mathrm{D}}$ where $\mathrm{PM}$ is known as an import deflator which is calculated by dividing imports at current prices by imports at constant prices, PD is known as the export deflator and is calculated by dividing exports at current prices by exports at constant prices. ${ }^{1}$ All variables are expressed in natural logarithmic form.

Table 1 below is a summary of the descriptive statistics of the involved variables in the study.

Table 1: Summary statistics for the series

\begin{tabular}{ccccc}
\hline & LNM & LNBC & LNRGDP & LNRP \\
\hline Mean & 26.181 & 27.536 & 28.111 & -0.675 \\
Median & 25.966 & 27.477 & 28.102 & -0.548 \\
Maximum & 27.140 & 28.362 & 28.732 & 0.660 \\
Minimum & 25.390 & 26.682 & 27.389 & -2.275 \\
Observations & 50 & 50 & 50 & 50 \\
\hline
\end{tabular}

The study then investigated the stationarity properties of the data. This was done to avoid estimating an equation that would yield spurious results or regressions with non-stationary series. The Dickey Fuller GLS test was used and the results of the unit root tests are shown below in Table 2 .

Figure 1 plots the individual time series of the data employed in this study in their natural logarithms. A stationary series is characterized by a time-invariant mean and a time-invariant variance. There are alternative methods that are used to test for stationarity of a time series. In this study we use the Dickey-Fuller GLS test to examine the unit root properties of the

\footnotetext{
${ }^{1}$ For a similar treatment see Giovannetti (1989)
} 
data. The results reveal that the null hypothesis of unit root is not rejected in levels for all variables, but is rejected in first differences. A constant and trend were included in these tests. Table 1 presents the DF-GLS unit root test results. The unit root test results show that all the variables are integrated of order one, I (1).
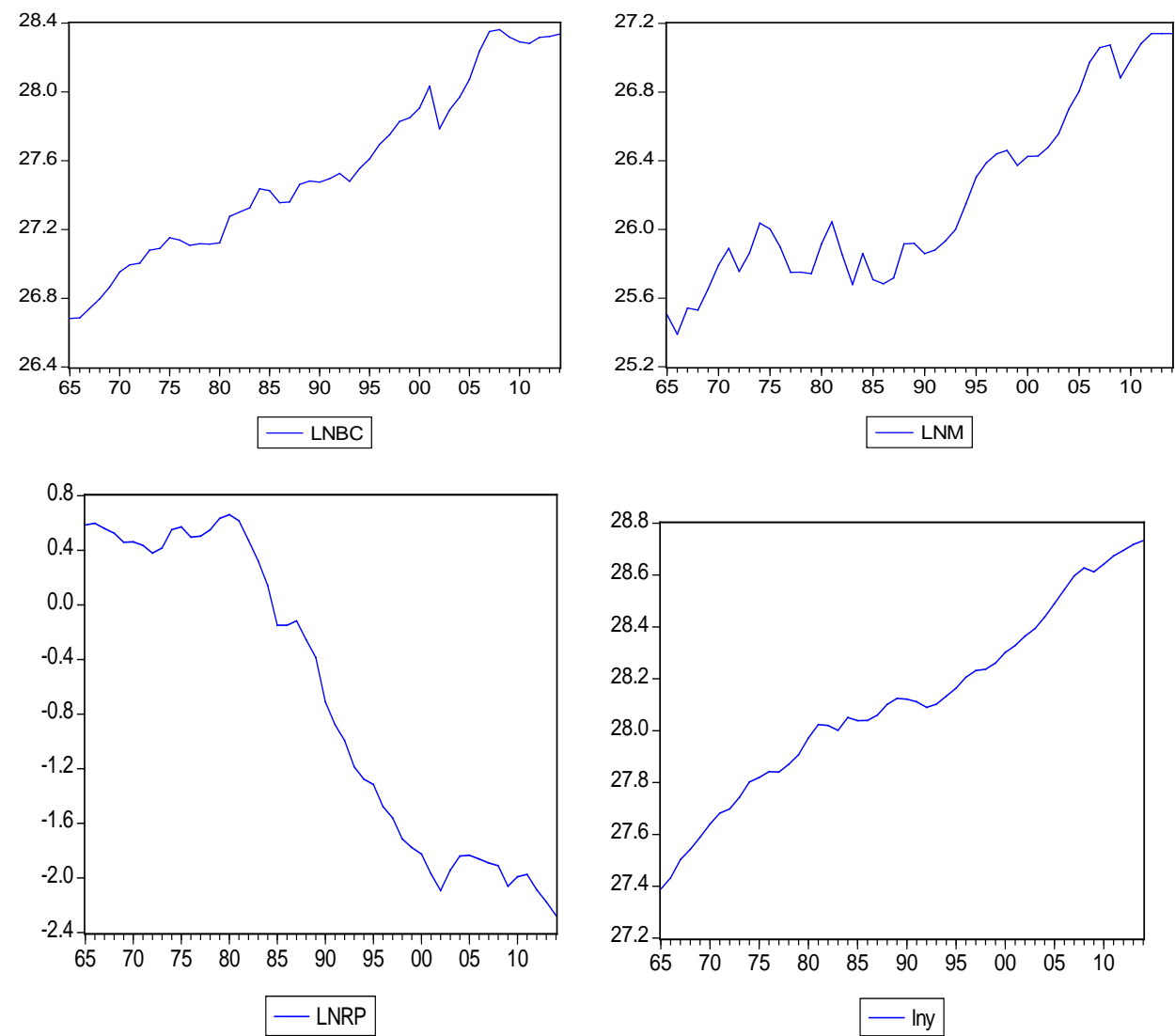

Figure 1.Plot of time series in natural logarithms

Table 2. Unit root test results: DF-GLS

\begin{tabular}{|c|c|c|c|}
\hline \multirow{2}{*}{ Variable } & \multicolumn{2}{|c|}{ Levels } & First difference \\
\hline \multirow{2}{*}{ LnM } & Intercept & $0.755(-1.612)$ & $-4.803^{* * *}(-2.614)$ \\
\cline { 2 - 4 } & Trend \& intercept & $-1.743(-2.890)$ & $-5.978^{* * *}(-3.770)$ \\
\hline \multirow{2}{*}{ LnBC } & Intercept & $1.206(-1.613)$ & $-6.817^{* * *}(-2.614)$ \\
\cline { 2 - 4 } & Trend \& intercept & $-2.824(-2.890)$ & $-7.077^{* * *}(-3.770)$ \\
\hline \multirow{2}{*}{$\operatorname{lnRP}$} & Intercept & $0.444(-1.612)$ & $-3.964 * * *(-2.614)$ \\
\cline { 2 - 4 } & Trend \& intercept & $-1.591(-2.890)$ & $-4.196^{* * *}(-3.770)$ \\
\hline \multirow{2}{*}{$\ln \mathrm{I}$} & Intercept & $0.875(-1.612)$ & $-4.354^{* * *}(-2.614)$ \\
\cline { 2 - 4 } & Trend \& intercept & $-1.83(-2.890)$ & $-4.657^{* * *}(-3.770)$ \\
\hline
\end{tabular}

$* * *$ denote rejection of a unit root null hypothesis based on MacKinnon's critical value at $1 \%$. The numbers in the parentheses for the levels are the critical values at $1 \%$ and $10 \%$ level. 


\section{Cointegration test results}

Table 3: UECM for Aggregate Import Demand Function

\begin{tabular}{cccc}
\hline Variable & Coefficient & t-statistic & probability \\
\hline Constant & -1.962 & -1.163 & 0.252 \\
LNM(-1) & -0.104 & -1.829 & 0.075 \\
LNBC(-1) & -0.251 & -1.887 & 0.067 \\
LNRGDP(-1) & 0.408 & 2.888 & 0.006 \\
LNRP(-1) & -0.045 & -1.965 & 0.056 \\
$\Delta$ (LNRGDP) & 4.297 & 10.615 & 0.000 \\
$\Delta$ (LNRP(-2)) & -0.249 & -2.234 & 0.031 \\
& & & \\
Adjusted R $^{2}$ & 0.763 & & \\
F-statistic & 25.67 & & \\
Durbin Watson stat & 1.572 & & \\
\hline
\end{tabular}

Table 4: Specification \& diagnostic tests for the import demand function

\begin{tabular}{clc}
\hline Jarque-Bera test & JB: & $0.532(0.766)$ \\
Ramsey RESET test (2) & F-statistic: & $0.493(0.615)$ \\
White heteroskedasticity test & F-statistic: & $0.704(0.797)$ \\
Breusch-Godfrey LM test & F-statistic: & $1.207(0.310)$ \\
ARCH test(2) & F-statistic: & $0.939(0.338)$ \\
\hline
\end{tabular}

Number in brackets indicates P-value

Diagnostic tests of the UECM reported in Table 4 above revealed an absence of major diagnostic problems. The Jarque-Bera test confirms residual normality. The Ramsey RESET test indicates an absence of the general specification error. The White heteroskedasticity test rejects the presence of heteroscedasticity. The Breusch-Godfrey LM test does not reject the null hypothesis of no serial correlation.

The co integration test under the bounds framework involves the comparison of the F-statistic against the critical values for a given sample size. Our bounds test co integration test results are reported in Table 5 below.

Table 5 presents the results of the estimation of an unrestricted error correction model (UECM) of equation (7). The optimal lag length (n) for the UECM is selected using the Akaike information criterion (AIC). The general UECM is tested downwards sequentially to arrive at a parsimonious model. By comparing the calculated $F$-statistic to the critical values we can see that the null hypothesis of no long-run relationship is rejected in the case where trade balance is the dependent variable. The calculated F-statistic of 4.12 is greater than the upper bound of 3.973 at $10 \%$ level. The unique cointegrating relationship among these variables is also confirmed by the multivariate Johansen-Juselius approach to cointegration.

Table 5. Bounds testing procedure results

\begin{tabular}{|c|c|c|c|}
\hline Dependent variable & $F$-statistic & \multicolumn{2}{c|}{ Critical bounds at $10 \%$} \\
\hline & & Lower bound I(0) & Upper bound I(1) \\
\hline$F_{\mathrm{M}}(\mathrm{M} / \mathrm{Y}, \mathrm{RP}, \mathrm{BC})$ & 4.12 & 2.873 & 3.973 \\
\hline \multicolumn{2}{|c}{$*$ denotes statistical significance at $5 \%$ level. }
\end{tabular}


Number of regressors $=3$. Critical values are obtained from Narayan (2005) for 50 observations. Case III is for unrestricted intercept and no trend.

Table 5 shows that the computed F-statistic is 4.12 and with $\mathrm{k}=3$, the lower and upper bounds are 2.873 and 3.973 respectively at $10 \%$ level of significance. Since the computed F-statistic lies above the upper bound, the null hypothesis can be rejected; indicating co-integration and therefore a long run relationship among the variables.

The study found the presence of co integration and therefore a long run relationship between import demand and its determinants. Thus, the next section will estimate and analyze the long run elasticities of imports with respect to the specified explanatory variables.

\section{Long-run Elasticities}

Having confirmed the presence of co-integration and hence a long run relationship between import demand and bank credit. There is need to estimate the long run elasticities using the ARDL approach as specified in equation (5).

Table 6: long-run elasticities $(2,1,2,1)$

\begin{tabular}{cccc}
\hline Variable & Coefficient & T-statistic & Probability \\
\hline LNBC & 0.172 & 1.160 & 0.253 \\
LNRGDP & 4.138 & 10.301 & 0.000 \\
LNRP & -0.044 & -1.904 & 0.064 \\
LNM(-1) & 1.065 & 7.816 & 0.000 \\
LNBC(-1) & -0.305 & -1.943 & 0.059 \\
LNRGDP(-1) & -5.433 & -6.176 & 0.000 \\
LNM(-2) & -0.183 & -1.559 & 0.127 \\
LNRGDP(-2) & 1.543 & 2.337 & 0.025 \\
C & -0.309 & -0.200 & 0.842 \\
Adjusted R & 0.989 & & \\
F-statistic & 561.2 & & \\
DW & 1.935 & & \\
\hline
\end{tabular}

The above results show that the variables except exports show the correct signs i.e. in accordance with economic theory. Economic theory suggests that there is a positive relationship between bank credit and import demand. However, the bank credit coefficient is not statistically significant. A negative relationship between relative import price and the quantity of imports is observed as hypothesized. A positive relationship between the economic activity variable and the quantity of imports is observed as is expected. The economic activity variable is statistically significant at 1 percent level while the relative price variable is significant at the 10 percent level of significance. 
An increase in real gross domestic product by $1 \%$ increases the level of imports by $4.1 \%$. An increase in relative price by $1 \%$ reduces imports by $0.044 \%$ as there is an inverse relationship between the two as shown by the negative coefficient. The major determinants of the South African aggregate imports in the long run are relative price, and the level of income. The import price elasticity is inelastic as theory would suggest.

The study then applied the CUSUM and CUSUM of squares to check the stability of the import demand function. The model appears to be correctly specified and generally stable as neither the CUSUM nor the CUSUM of squares exceeded the bounds of the $5 \%$ level of significance as shown in figures 2 and 3 below.

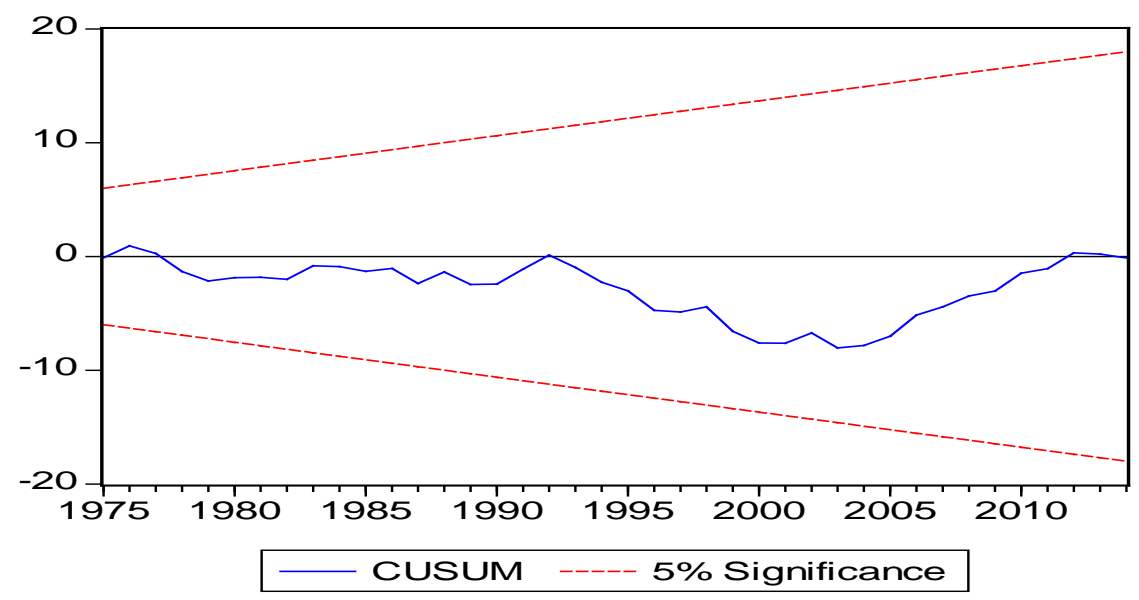

Figure 2. Plot of CUSUM

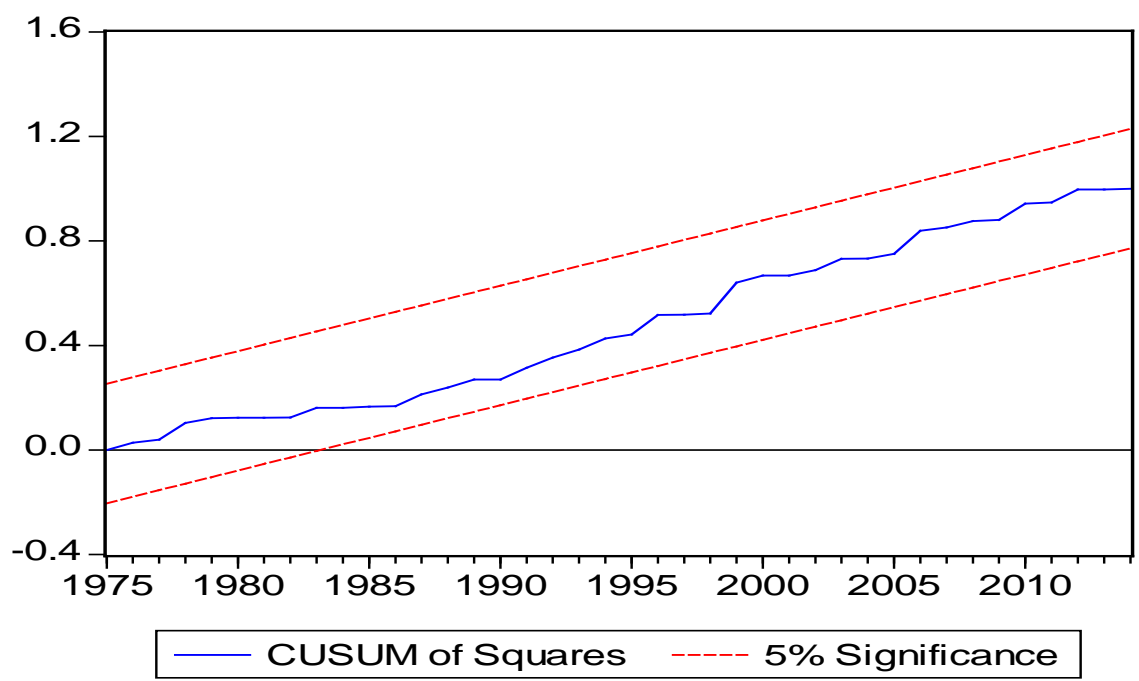

Figure 3. Plot of CUSUMSQ 
The model appears to be correctly specified and generally stable as neither the CUSUM nor the CUSUM of squares exceeded the bounds of the $5 \%$ level of significance.

\section{Short run behaviour of the South African aggregate imports}

The study also examined the short run behaviour of aggregate imports by estimating a dynamic error correction model (ECM). For the above stated purpose, a lagged residual error derived from the co-integrating equation was incorporated into the general error correction model. The general short run ECM was estimated above as equation (6) and the results are reported in Table 7.

Table 7: Short run elasticities $(2,2,1,0)$

\begin{tabular}{cccc}
\hline Variable & Coefficient & t-statistic & Probability \\
\hline ECM(-1) & -0.187 & -2.629 & 0.012 \\
$\Delta$ (LNBC) & 0.288 & 2.110 & 0.042 \\
$\Delta$ (LNRGDP) & 3.960 & 7.981 & 0.000 \\
$\Delta$ (LNRP) & 0.028 & 0.238 & 0.813 \\
$\Delta$ (LNM(-1)) & 0.323 & 2.580 & 0.014 \\
$\Delta$ (LNBC(-1)) & -0.297 & -1.933 & 0.061 \\
$\Delta$ (LNRGDP(-1)) & -1.641 & -2.347 & 0.024 \\
$\Delta$ (LNM(-2)) & 0.139 & 1.519 & 0.137 \\
$\Delta$ (LNBC(-2)) & -0.212 & -1.519 & 0.137 \\
Constant & -0.033 & -1.609 & 0.116 \\
Adjusted R & 0.750 & & \\
F-statistic & 16.358 & & \\
DW & 1.999 & & \\
\hline
\end{tabular}

The general model was tested with the appropriate number of lags as 2 periods as determined by the Akaike's information criterion. The coefficient of the error correction term is negative and statistically significant which reconfirms the presence of a long run equilibrium relationship among import and expenditure components. $E C M_{\mathrm{t}-1}$ measures the speed at which import demand adjusts to changes in the explanatory variables before converging to its equilibrium level. The estimated coefficient of the error correction term indicates the speed of adjustment among the variables within a year. This means that the model will correct about $19 \%$ of the system disequilibrium within a year and achieve long run equilibrium after 5.3 years.

\section{Summary and policy implications}

The main objective of this paper was to examine the impact of bank credit on the South African aggregate import demand function for the period 
1965 to 2014 using the bounds test for a co-integrating relationship. Unit root tests confirmed that all variables in the import demand function were non-stationary. Our empirical results suggest that there exists a long-run relationship between aggregate imports, national income, bank credit and the relative price of imports. The results of the study may be summarized as follows.

Firstly, the estimated import demand function fits the data well and all the statistically significant coefficients have the correct signs according to economic theory. The coefficient for bank credit is positive but statistically insignificant in the long run. It is however, statistically significant at the 5 percent level of significance in the short-run. Secondly, the stability tests suggest evidence of structural stability in the parameters during the sample period. Thirdly, the use of co integration and autoregressive distributed lag model has yielded useful results. The study found evidence of a co integration relationship among the variables in the import demand function.

These empirical results have significant policy implications on the economic policies designed to improve South Africa's trade performance in the short and long run. Firstly, the demand for imports was found to be price inelastic. The implication of this result is that trade and exchange rate policies may not be as effective in regulating imports (current account deficit) as is generally believed by policy makers. Secondly, bank credit can only be used to control import demand in the short-run. Thus, reducing bank credit can help reduce the current account deficit only in the short-run.

In the short-run, an error correction model appears to perform well providing an appropriate framework for forecasting the short-run fluctuations in the South African aggregate imports.

\section{References:}

1. CRAIGWELL, R. 1994. Modelling Aggregate import Demand in Barbados. Working paper of the Central Bank of Barbados.

2. GIOVANNETTI, G. 1989. Aggregate Imports and Expenditure Components in Italy: An Econometric Analysis. Applied Economics, 21, pp. 957-971.

3. GUMEDE, V. 2000. Import Demand Elasticities for South Africa: A Cointegration Analysis. Journal of Studies in Economics and Econometrics, 24, pp. 21-37.

4. NARAYAN, P.K. 2005. The saving and investment nexus for China: evidence from cointegration tests. Applied Economics, 37(17), pp. 1979-1990.

5. NARAYAN, P.K., \& NARAYAN, S. 2005. Estimating income and price elasticities of imports for Fiji in a cointegration framework. Economic Modelling, 22, pp. 423-438. 
6. OMOKE, P.C. 2012. Bank credit and aggregate import demand in Nigeria: A cointegration analysis. Acta Universitas Danubius, 8 (3), pp. 28- 37.

7. PESARAN, M H., SHIN, Y \& SMITH, R. J. 2001. Bounds Testing Approaches to the Analysis of Level Relationships. Journal of Applied Econometrics 16(3), pp. 289-326.

8. SENHIDJI, A. 1998. Time series estimation of structural import demand equations: A cross-country analysis. IMF Staff papers, 45, pp. 236-268.

9. STRAUS, I. 2015. Understanding South Africa's current account deficit: The role of foreign direct investment income. AfDB Africa Economic Brief, volume 6, issue 4.

10. TANG T.C. 2004. Does financial variable(s) explain the Japanese aggregate import demand? A cointegration analysis. Applied Economics Letters, 11, pp. 775-780.

11. TANG, T.C. 2006. Aggregate import demand and bank credit in Southeast Asia: An Empirical Study. International Journal of Economics and Management, 1(1), pp. 117 -139.

12. TRUETT, L J \& TRUETT, D B. 2003. A cost function analysis of import demand and growth in South Africa. Journal of Development Economics, 70(2), pp.425-442.

13. ZIRAMBA, E. 2008. A cointegration analysis of South African aggregate import demand function: Assessment from bounds testing. Journal of Studies in Economics and Econometrics, Volume 32(1), pp. 89-101.

14. ZIRAMBA, E. 2012. Revisiting the South African aggregate import demand: a view from expenditure components. Journal of Studies in Economics and Econometrics, 36(2), pp. 67-83. 